\title{
De lokale-globale danskere: En journalistisk udfordring Mediernes udfordring er at skabe rum for en kritisk lokal-global offentlighed
}

\section{AF HANS-HENRIK HOLM}

Hvor globale eller hvor lokale er danske medieforbrugere? Forestillingen om det globale og det lokale modstilles. Udfordringen for journalistikken er, at vi er både globale og lokale, og at medieindholdet må afspejle den dobbelthed. Specielt vanskeligt er det at kombinere, når globale og lokale holdninger og normer støder sammen. Mediernes nationale dagsorden påpeges som utilstrækkelig til at imødekomme forbrugernes behov.

Globaliseringen forandrer Danmark. Det er ikke så underligt, at globalisering er blevet et modeord. Som et relativt åbent lille samfund påvirkes Danmark meget. I et homogent samfund bliver den grænsenedbrydende globalisering til et særligt mærkbart fænomen. Krisen om Jyllands-Postens tegninger har gjort det klart for alle. Tegninger i en dansk avis fører til voldsomme reaktioner i en helt anden del af verden og fører igen til en skarp polarisering af dansk politik.

Men hvad er konsekvenserne for den måde, vi orienterer os på i verden? Presser globaliseringen ændrede interessemønstre frem blandt danskerne? Bliver folk mere interesserede i den store verden? Vil den globaliserede dansker efterspørge mere information og mediestof fra den store verden, fordi hun føler, at den er flyttet tættere på? Har globaliseringsbølgen skabt nye interesseområder hos danskere? Er danskerne blevet globale? 
Svaret er ikke så selvindlysende, som det måske kan synes. Globaliseringen kan af mange opleves som en trussel. Globaliseringen skaber modstand. Under debatten om tegningerne udtalte Dansk Folkepartis leder Pia Kjærsgaard: ,,Vi vil have lov til at have dette lille land i fred-sagt meget firkantet. Men selvfølgelig ikke så meget $i$ fred, som jeg altid husker at sige, at vi ligefrem skal isolere os" (Jyllands-Posten, den 19. marts 2006).

Tilhængere af det globale perspektiv ser det lokale perspektiv som noget fra fortiden, en atavisme. De ser det globale perspektiv sprede sig som ringe i vandet blandt befolkningen. De ser „lokale tilbageslag“ som kortvarige og begrænsede retursving på en fremad orienteret udvikling. Globaliseringen ses som et mere moderne udviklingstrin, der har erstattet traditionelle og præmoderne samfundsformer. Nogle globalister mener, vi er på vej ind i et postmoderne globalt system, hvor forskellige netværk skaber samfund, der er skåret op på kryds og tværs. De er globale, men forskellige.

Den globale nedbrydning af grænser og barrierer vil fortsætte, fordi den presses frem af ønsket om økonomisk velfærd og teknologiske forandringer. Informationssamfundet er globalt, og før eller siden vil hovedparten af læserne også blive det.

Tilhængerne af det lokale perspektiv er en mere sammensat gruppe. På den ene side er der folk, som ser det globale samfund som en trussel mod nationale værdier og arbejdspladser. De ønsker derfor at fremme en politisk udvikling, der sætter nye barrierer op og fastholder stater og samfundsret til større selvbestemmelse. I en del af det politiske spektrum lægges vægten på vores ret til at have vores land i fred, som Pia Kjærsgaard udtrykker det. Her er det vores værdigrundlag, normer og sædvaner, der skaber grundlaget for modstanden mod værdisæt, der er anderledes. Vi bliver truet af fremmedartede værdier, og skal fastholde vores ret til at afvise dem. Vi skal ikke relativere vores værdiopfattelse for at imødekomme andres værdier. I følge en JP/Rambøll undersøgelse af den danske befolknings holdninger til muslimer i Danmark mener 22,2 procent, at „det store antal muslimer i Danmark gør, at jeg af og til føler mig som en fremmed i mit eget land." Blandt personer over 65 år er det 34,8 procent, der har det sådan (JP/Rambøll, 2006). 
På den anden side er der folk, som ser det lokale, som løsningen på de problemer vi står overfor. Det er i en alternativ økonomisk, social og miljømæssig udvikling, at bæredygtig udvikling skal findes. En økonomi, der sender vand i flasker rundt i verden, fordi det er bedre at drikke Perrier vand end det lokale kildevand, er ikke bæredygtig på langt sigt, mener de aktive lokale.

Globaliseringen skaber både interesse for det globale, men også modstand. Tendenserne har fået flere globaliseringsteoretikere til at tale om, hvordan globaliseringstendenserne styrker det lokale tilhørsforhold. Vi bliver både mere lokale og mere globale på samme tid. Men vores politiske og mediemæssige offentlighed er stadig national.

\section{Meget mere verden i medierne}

Vi spejler vores globale interesser i vores medieforbrug. Både aviser og elektroniske medier giver i dag et bredt udbud af information, kultur og underholdning fra mange forskellige dele af verden.

Vi har rejseprogrammer fra alle dele af verden. Vi har madprogrammer med udenlandske kokke. Vi har boligprogrammer om Bulgarien og Tyrkiet. Vi har operaomtaler af forestillinger i London, Hamburg, og Paris. I bogen: „Verden på tilbud“ lavede vi en analyse af bredden i den moderne dækning af omverdenen og påviste, hvor sammensat og gennemgribende den globale verden sætter sig spor i mediernes indhold (Holm et al., 2000).

Der er en vækst i både omfang og variation af den mediemenu, vi får stillet til rådighed. Der er mere om verden. Et eksempel er udenrigsdækningen i Jyllands-Posten. Her er udenrigsstoffet steget fra $34.224 \mathrm{~cm}^{2}$ i 1962 til $45.698 \mathrm{~cm}^{2}$ i 1982 og $83.251 \mathrm{~cm}^{2}$ i 2002 . Det er en stigning på over 140 pct. Den geografiske dækning er også blevet bredere. I 1962 var 65 pct af dækningen om Europe, mens Asien/Mellemøsten var på 3 pct. I dag er Europadækningen faldet til 32 pct og Asien/Mellemøsten er steget til 28 pct. Nye emner er også kommet frem. Specielt markant er det, at 24 procent af stoffet nu er om erhvervs- og markedsforhold i andre lande. Det var fraværende i 1962 (Haahr og Holm, 2003: 146). 
Der er ingen tvivl om, at vi i dag har betydelig mere viden om vores omverden, end vi havde for tyve eller fyrre år siden. Medierne har en meget vigtig rolle $i$ at bringe viden om verden frem til os. Men hvad betyder det for vores holdninger til det fremmede? Bliver vi skræmte over de voldsomme ting, vi møder i verden omkring os, eller bliver vi bange for, at vi ikke længere kan kontrollere udviklingen og vores liv og jobbetingelser på same måde som tidligere? Svaret er, at „verden“ både truer og lokker os. Men de fleste oplever det som uomgængeligt, at det er sådan.

Vi har fået brug for verden. Informationer om politiske, økonomiske og kulturelle forhold i andre lande og samfund er i dag en vigtig forudsætning for, at mange danskere kan løse deres daglige arbejdsopgaver. Vi har brug for selvstændig information indhentet og tilpasset danske behov og dansk mentalitet. Der er derfor langt flere journalister i dag, der arbejder med det internationale stofområde end tidligere. I 1962 var de fleste af artiklerne fra et af nyhedsbureauerne, mens i dag er næsten 80 procent af artiklerne signeret af avisens egne journalister.

For fyrre år siden var omverdenen små, interessante eller fascinerende nyheder. Næsten en femtedel af alle nyhederne om den store verden i 1962 var små notitser. Her samlede man alle de små og store nyheder om den forunderlige verden. Her er ti linjer om, at den norske grundlov er ændret og ti linjer om, at russerne fik surrogatbrød under Stalin. Her er historien om masseflugt af sumpbævere fra en farm i Norwich, hvor et uvejr havde ødelagt hegnet, og historien om Grønlands første bilturist (JP, marts 1962).

Den store verden var et reservoir af forunderlige og mærkelige begivenheder, som datidens avislæsere kunne fascineres af. Den slags er erstattet af historier om kursbevægelser på New York's børs, virksomhedssammenslutninger i Japan og ændringer i den $ø$ konomiske politik i Indien.

Medierne tegner i dag et billede af en global verden, hvor koblingerne til den enkelte dansker og konsekvenserne af, hvad der sker i omverdenen er tydelige. Vi har behov for at få mere at vide både om trusler og om mulighederne, og det får vi så.

På trods af de store forskelle mellem dengang og nu, er der også ligheder. De danske medier er stadig meget danske. Vi kender det 
alle godt. Vi kommer hjem fra ferie i udlandet, hvor vi ikke har set nyheder eller læst aviser i en længere periode, og vi undrer os over, hvad der er de store nyheder i Danmark.

Det som nogen meget rammende har kaldt DNV: „Dansk normal virkelighed“: Den særlige virkelighed der skabes gennem danske mediers prioritering, udvælgelse af og vinkling af nyhederne. Skal vi have en ny motorvej eller ikke. Skal sommerferien flyttes med en uge, eller skal den ikke. Skal eleverne have to eller fire timers historie i tredje klasse? Vigtige spørgsmål i det lokale perspektiv, som udgør en stor del af vores fælles nationale referenceramme.

Det danske perspektivs dominans viser sig også i vores syn på, hvad der er fremmed, og hvem der er fremmed. I medieteorien kalder man det framing. Det filter, vi lægger ned over en historie, skaber en særlig ramme, som vi ser omverdenen igennem.

Vi ved måske mere i dag om Mellemøsten og mere om muslimer, men om den viden har flyttet os til en større forståelse er sværere at sige. Vi får en bestemt synsvinkel på islam præsenteret gennem medierne. Den synsvinkel er valgt, fordi den passer ind $\mathrm{i}$ den danske sammenhæng. Muslimer er interessante at skrive om, fordi vi har en stor politisk diskussion, om hvor meget indvandring vi skal tillade til Danmark. En opinionsundersøgelse fra maj 2006 viser, at et klart flertal af danskerne mener, at man bør begrænse muslimers indvandring til Danmark. I alle aldersgrupper bortset fra de 18-25 årige er der et klart flertal for begrænsninger. Det perspektiv er sat af debatten om arrangerede ægteskaber og fundamentalistiske muslimer. Terrordebatten passer ind i denne framing. Det er islam, der angriber os. Det er én måde at se tingene på som sætter rammerne for, hvordan vi opfatter andre problemer, der handler om samme emne. Mere end 76 procent af danskere over 65 år støtter begrænsninger på muslimers indvandring til Danmark (JP/Rambøll, 2006).

Et andet eksempel er debatten om EU. Der er igennem mange år lavet detaljerede analyser af vores viden om EU. Her ligger Danmarki den europæiske top. Vi ved mere om EU's institutioner og regler end de fleste andre lande i EU, men vi er også stadig et af de lande, der har den største skepsis overfor EU's institutioner og regler. Danmark er splittet i to næsten lige store halvdele, når 
det kommer til holdningen til EU. Én halvdel, der er skeptisk overfor integration og én, der er mere positiv. Den megen viden, vi har fået gennem folkeafstemninger og lignende, har betydet, at vi har taget stilling: Lige mange for og lige mange imod. Viden har vi fået, men også en bestemt framing af debatten (Ørsten, 2006).

De foreløbige undersøgelser af konsekvenserne af Muhammed-krisen viser noget af det samme. Også her har vi fået mere viden om muslimer og islam og også her er befolkningen delt op i to næsten lige store halvdele: Én gruppe, der står fast på danske regler og normer, og en anden (specielt de yngre) der lægger mere vægt på det globale og det kulturforstående.

Viden er ikke det samme som forståelse eller accept. Den journalistiske udfordring er, at forholde sig kritisk til den nationale framing, der fører til opdelingen af befolkningen i to grupper: en lokal og en global. Men hvad vil det sige at være global eller lokal?

Der sidder de så - de to danskere. Den „lokale“ vil vide, hvad der sker her, hvor vi er: henne på hjørnet. Det vi kender, og der hvor vi har været. Hun vil have orden i sit verdensbillede. Det internationale interesserer hende kun, når der er noget $\mathrm{i}$ brændpunktet.

Den „globale“ har opgivet at få orden i sit verdensbillede, men vil gerne have orden i sine informationer. Han vil lige så gerne høre om børnesoldater i Uganda som om budgetforhandlinger på rådhuset. Han vil have sin verden beskrevet både globalt og lokalt og mener, de er to sider af samme sag. Brændpunkter er han træt af.

I mange år har den „lokale“ og den „globale“ kunnet føre en fælles samtale om det nationale. Her mødtes deres to verdener i en fælles national offentlighed. Men i de senere år er det blevet vanskeligere og vanskeligere for de to at tale sammen.

Hvordan ser den danske mediebruger på det internationale stof? Hvordan vil det danske mediebehov ændre sig i de kommende år? Vil vi flytte tættere på det globale menneske, eller vil vi være at finde henne om hjørnet på den „lokale“? Hvordan skal stoffet produceres og prioriteres?

Hvad indeholder de to perspektiver? Hvilket teoretisk grundlag bygger de på? Hvilket medieindhold efterspørger den globale og den lokale? De to perspektiver blive ridset op for at understrege 
forskellene mellem dem. De er stillet op som en slags idealtyper. Det vil sige vægten er lagt på at beskrive det centrale indhold i de to perspektiver. Målet er at give baggrunden for den journalistiske udfordring, der ligger i det globale og det lokale perspektiv.

\section{Den globale landsby}

Vi lever i en global landsby. Vi hører det ofte. Det er næsten blevet en kliche. Men hvad betyder det? Der er et radikalt indhold og et universelt perspektiv bag klicheen. I en global landsby er grænserne ophævede. Her er sted og tid ophævet som vigtige kategorier og erstattet af en form for global civilisation, en global bevidsthed, et globalt marked. Hvad der før var lokalt, og senere blev nationalt, er nu blevet globalt (Waters, 1995: 14).

Begrebet den globale landsby viser, at verden er blevet større og mindre på en gang. Mindre, fordi det er blevet nemmere at rejse og kommunikere over store afstande. Større, fordi man får udvidet sine horisonter. Landsbyen er blevet global.

Geografisk eller kulturel afstand er ikke centrale dimensioner for det globale menneske. Verden er i stedet skåret op på kryds og tværs. Nogle har kaldt det forskellige „landskaber“ (Appadurai, 1991: 297). Verden består af overlappende perspektiver eller images, der strukturerer vores opfattelse og identitet. Der er et „tekno-landskab“, hvor verden skabes af de teknologiske muligheder og forskelle mellem samfund. Der er et „ethno-landskab“, hvor befolkningsfordelinger og befolkningsbevægelser skaber nye former for identifikation sammenhold og modstand, når homogene samfund kommer i bevægelse.

Der er også et „medie-landskab“. I det globale medie-landskab bliver strimler af virkeligheden til vinkler og historier, der giver liv til centrale metaforer om verden og om omverdenen. Under Irak krigen i foråret 2003 var der stor forskel på mediedækningen i lande som Tyskland, Storbritannien og USA. Mange medier i USA gav en patriotisk dækning af krigen. I Tyskland var det kritikken af krigen, der var det dominerende tema i medierne. I Storbritannien fandt man begge dele. Vores holdning til krig som middel og vores holdning til muslimer præges af, hvordan medielandskabet er udformet (Allan og Zelizer, 2004: 3). Eksisterende forskning har 
påvist, at vores grundlæggende forståelse af, hvordan verden er sat sammen præges af, hvordan nyhederne fortælles. I de rige lande har vi for eksempel opbygget et billede af Afrika som et kontinent med sult, fattigdom og hjælpeløshed (Holm, 1994: 13).

Globaliseringen er i dag et velkendt fænomen, men der findes to forskellige opfattelser af, hvad globalisering er. I den første fase af globaliseringen blev den set som en slags global homogenisering (McLuhan, 1964; Keohane, 2000; Negroponte, 1995). Vi ville alle blive mere ens. I senere forståelser lægges der vægt på, at globaliseringen skaber et utal af overlappende netværk. Her betyder globaliseringen ikke homogenisering, men måske det modsatte. Den samme globale påvirkning skaber meget forskellige effekter i forskellige netværkssammenhænge (Hirst, 1996; Held, 1999; Castells, 1997).

Den globale landsby er ikke et homogent hele, men et opsplittet kalejdoskop af landskaber, der overlapper, står i modsætning til hinanden og er i konstant udvikling. Men landskaberne er globale. De er universelle uden at være homogene. Irakkrigen var en fælles dagorden i medierne overalt, men der var store forskelle i den ramme, nyhederne nationalt blev sat ind i. Det er nyt.

I den første fase af globaliseringen efter Anden Verdenskrig blev den set som en kraft, der skabte en homogenisering af verden. Gradvist blev vi alle mere og mere ens, efterhånden som vi kom i berøring med globaliseringen. Allerede i 1964 formulerede Marshall McLuhans begrebet om ,the global village." (McLuhan, 1964: 7). Tankegangen her er, at den fortsatte udvikling af teknologi og kommunikation vil føre til en stadig nedbrydning af nationale politiske, sociale og kulturelle barrierer.

„Som elektrisk sammentrukket, er verden kun en landsby. Elektronisk hastighed bringer alle sociale og politiske funktioner sammen $i$ en implosion, der har forøget menneskelig bevidsthed om ansvarlighed til en uset grad. Det er denne implosion, der cendrer negerens, teenagerens og andre gruppers placering. De kan ikke loengere inddcemmes. De er nu involveret i vores liv, som vi er i deres takket vaere de elektriske medier."(McLuhan, 1964: 5).

Konsekvensen af denne øgede berøring mellem folk er en øget følelse af fællesskab, mener globaliseringsteoretikerne. Den samme musik, de samme film, de samme emner i nyhederne 
skaber en udvidelse af det geografiske rum, hvor der er et oplevet fællesskab. Vi kan rejse jorden rundt og finde den samme film i biografen i Lusaka og i Lemvig. Der høres på den samme rapmusik i Hanoi og i Hobro. Men er der noget fællesskab i det?

Jo bredere et fælles rum er, jo tyndere er fællesskabet. Det er et tyndt fællesskab, hvis det er bundet til få fælles oplevelser ved musik eller tv eller medieforbrug. Teenagere fra USA, Europa og Japan kan opleve et fællesskab om den samme musik, de samme tv-serier, men bliver de mere ens af den grund? Selvom påvirkningerne gennem medierne verden over er de samme, så er konteksten de forbruges i stadig radikalt forskellig. Men globaliseringsteoretikere forventer, at der gradvist vil blive flere og flere fællesoplevelser, så fællesskabet bliver tykkere og tykkere. Først er det musik eller tv, så bliver det måske rejse eller studieophold. Dernæst personlige venskaber. Gradvist bliver fællesskabet tykkere (Volkmer, 1999). Selvom der er store forskelle i dag, så er forventningen, at den bliver mindre over tid.

Den stigende globalisering af nyhedsformidlingen er et vigtigt led i at skabe tykkere fællesskabslag. Der sættes flere og flere fælles globale emner på dagsordenen samtidig overalt på kloden. Synsvinklerne på mange af historierne er de samme.

Undersøgelser af dækningen af introduktionen af Euroen i Danmark, Storbritannien og Holland viser stor overensstemmelse i hvilke vinkler, der vælges (Vreese, 2000: 182). Terrorangrebene den 11. september 2001 var en omgående global begivenhed. De samme informationer og de samme billeder blev brugt til at fortælle nyheden overalt og samtidig. Tsunamien i julen 2004 var ikke alene en fælles stor mediebegivenhed, men førte også til en global bevægelse for at gøre noget for ofrene. Begivenheden skabte en global- omend kortvarig medieoffentlighed.

I den såkaldte vestlige verden er det en udvikling, der har stået på i mange år. Den nationale nyhedsdagsordenen er blevet mere ens. Sammenligner vi tv-nyhederne i en række vestlige lande er det stort set de samme emner, der dækkes, og de dækkes på stort set samme måde. Der er få internationale tv-bureauer, og de bruges af alle tv-stationerne. Det betyder, at det er de samme billeder fra Palæstina, fra det tyske valg, af præsident Bush's tale, der ses i Holland, i Danmark, i USA og i Australien. Selv udenfor den vest- 
lige verden er nyhedshomogeniseringen i dag en realitet (Ginneken, 1998: 113).

Men bliver nyhederne opfattet ens? Skabes der et fællesskab? Dækningen af den 11. september angrebene illustrerede, at uanset at billederne var de samme, så udløstes der vidt forskellige reaktioner: Sorg ét sted, glæde andre steder. Sympati og opbakning i nogle lande, modstand i andre. Den meget forskellige dækning af Irak krigen i foråret 2003 gav yderligere illustration af, at der stadig er store nationale forskelle i nyhedsdækningen. Er globaliseringen så homogeniserende, som det så ud i den første fase?

Fællesskabslaget er tyndt, hvis det kun er baseret på den passive modtagelse af de samme oplysninger. Men globalisterne ser en verden på vej mod tykkere fællesskaber. Forskellene vil gradvist blive mindre, mener de. Den globale landsby betyder en større verden.

Hvis det globale fællesskab langsomt bliver tykkere og tykkere, bliver konsekvenserne mere og mere omfattende. National identitetsdannelse vil i stigende grad foregå i et mere åbent globalt rum. Her vil de tykkere globale lag skabe begyndelser til globale bevidstheder. Miljøbevægelser og menneskerettighedsbevægelser baseret på fælles transnationale forståelser lægger byggeblokke til global civilisatorisk bevidsthed (Hall, 1999).

I McLuhans radikale formulering bliver verden til ét centralnervesystem. Vi bliver alle dele af et gensidigt afhængigt organisk system, hvor ingen enkelt del længere kan skille sig ud eller „beskytte" sig.

Informationsalderens automatisering eller elektrificering, som McLuhan kalder det, har indbyggede sociale effekter, der på godt og ondt sætter sig igennem. På samme måde som valget af det latinske alfabet var en af forudsætningerne for modernisme og det industrielle gennembrud, så er „elektrificeringen“ den murbrækker, der henviser det lokale til frilandsmuseet (McLuhan, 1964: 385).

Nogle globaliseringsteoretikere mener, at den globale landsby betyder, at „vi og de“ opdelingen mindskes i betydning. Mange mener, at selve sondringen mellem, hvad der er internationalt og nationalt forsvinder (Giddens, 2000; Castells, 1997).

Globalisterne ser de centrale samfundsproblemer som græn- 
seoverskridende. Mange løsninger kan ikke længere baseres på nationale tiltag. Når man derfor søger efter internationale løsninger udvides den ramme, man ser problemerne $\mathrm{i}$, mener de. Man bliver om ikke international, så i hvert fald mere optaget af og påvirket af, hvad der sker internationalt.

For medierne og medieforbrugerne er konsekvenserne dramatiske. I takt med at globaliseringen nedbryder tradition og ,udvider selvet“ styrkes den enkeltes selvbestemmelse og autonomi. Det individuelle valg får større og større plads.

Mange globaliseringsteoretikere lægger derfor i dag afstand til McLuhans forestillinger om globaliseringens homogeniserende tendenser. De ser i stedet globaliseringen som sammensat af netværk, der integrerer på tværs af grænserne, men kun inden for adskilte områder. Bilindustrien er måske globaliseret, men der er stadig vidt forskellige nationale behov. Der er måske en global miljøbevægelse, men den har vidt forskellig gennemslag i forskellige kulturer og lande.

Det globale er sammensat af netværk, der integrerer på tværs af grænserne, og som fører til meget forskellige globale netværk. „Disse netværk gør mere end at organisere aktivitet og dele information. De er producenterne og fordelerne af kulturelle koder“ (Castells, 1997: 362).

Globaliseringen laver „huller“ i grænserne, der skaber ad-hoc fællesskaber i subkulturer. Miljøaktivister mobiliseres i mange lande samtidig og opbygger ens holdninger til globale problemer, men homogeniseringen er begrænset til det snævre område, og de bliver ikke nødvendigvis mere ens i deres syn på mange andre af livets forhold. Globale netværk kan skabes gennem fælles forbrug, fælles subkulturer eller fælles musiksmag, men disse fællesskaber er ad-hoc og ikke grundlag for en universel homogenisering. Det er homogene netværk, der skaber heterogenitet.

De „globale“ danskere er derfor ikke nogen homogen gruppe, der vælger ens i medieudbuddet. De tilhører forskellige globaliseringskulturer og har forskellige informationsbehov.

Når de „globale“ udvælger deres information dikteres deres valg i mindre grad af vaner og tradition. Nu bestemmes valget $\mathrm{i}$ højere grad af aktuelle behov og ønsker. Den „globale“ bruger medier, mange medier. For ham er der ingen vaner og traditioner, 
der får lov at bestemme. Hvis TV Avisen ikke giver de informationer, han har brug for, holder han op med at se den eller supplerer selv op. Han læser både avis og internet, hvis han har brug for det.

Han ser kritisk på mediernes indhold - hver dag. Han ønsker overskuelig information om de emner, han kommer i kontakt med i sin dagligdag, hvad enten det er lokale, nationale eller globale emner. Han ser ikke verden som opdelt på én måde, f.eks. i stater. Han ser ikke storpolitik som vigtigere end erhvervsstof eller kulturstof. Emnehierarkierne er nedbrudte for den globale læser. Det er ikke det nære, der er det vigtigste. For den „globale“ kan en nyhed fra Japan være lige så vigtig som én fra Tyskland eller fra Christiansborg. Det er emnet og interessen, der bestemmer, hvad der opfattes som væsentligt. Det er nytteværdien af information ikke karakteren af afsenderen, der afgør hans valg af medie. Den „globales“ interesse er individuelt defineret, og det kan være teknologi eller kultur, der står øverst på hans dagsorden lige nu. Det er derfor det stof, han efterspørger.

Den globale læser har for meget information til rådighed og har derfor et stort behov for, at der bliver skabt orden i hvilke informationer, der er vigtige og troværdige. Han ønsker viden om det globale hverdagsliv ikke kun om erhverv og politik. Han ønsker kontinuert dækning af „verden“. Han er ikke tilfreds med et fokus på brændpunkter.

Stoffet skal være let tilgængeligt, men for den „globale“ er det indholdet, der tæller. Et medie, der kun prioriterer det lokale, er lige så ubrugelig som et medie, der kun prioriterer det globale.

Men er sådan en "global“ en akademisk tankekonstruktion spundet af globaliseringsfanatikere? Er de fleste mennesker trods alt mest interesserede i det, der foregår lige uden for deres gadedør? Hvad med „den lokale“?

\section{Den lokale landsby}

Vi er født lokale. Det er gennem interaktion med vores nære omgivelser, at vi bliver, hvad vi er. Vores identitet bygger på social interaktion. Den første identitet børn udvikler er som medlem af en familie. Kontakten til en mor, far og søskende danner den første in-gruppe. 
Gradvist udstrækkes identiteten til at omfatte den skole vi går på, den bydel vi bor i. Cirklerne udvides langsomt op igennem opvæksten. De små grupper vi vokser op i, giver os samværsregler og måder at se os selv på. Herfra får vi forskellige former for traditioner. Vi ved, hvordan man fejrer jul, hvordan man siger goddag. Normerne, der styrer vores samvær med andre, defineres af vores kontakter med andre mennesker. Kombinationen af traditioner og identitet skaber social tryghed. Vi definerer os selv gennem et tilhørsforhold til en lokalitet, et sæt værdier og traditioner.

Identifikation kalder vi den proces, hvorigennem vi forstår os selv og erkender elementer i omverdenen, der er som os. Vi kan ikke forstå os selv uden at forstå de ting omkring os, der giver os identitet: sprog, familie, lokalsamfund og omgangskreds. Individer er ikke atomiserede enkeltdele af et samfund, men sociale væsner hvis værdier, holdninger og identitet skabes gennem deres sociale og lokale væren (Taylor, 1989; Mulhull and Swift, 1992).

Perspektivet den lokale landsby afspejler derfor et centralt træk i dannelsen af samfund: individets værdier, mål og interesser. Den lokale landsby er tryg. „Det er et varmt sted, et hyggeligt og komfortabelt sted. Det er som et tag, der giver os ly i den kraftige regn, som et ildsted, hvor vi kan varme vores hoender på en frostdag ... Vi kan slappe af ... vi føler os sikre, der er ingen farer i mørke hjørner. Vi forstår hinanden, vi stoler på, hvad vi får at vide, vi er sikre og der er sjceldent noget, der virkelig overrasker os. "Sådan skriver sociologen Zygmunt Bauman i sin bog „Fællesskabet“ (Bauman, 2001: 3).

Den lokale landsby er et ideal. Det er en slags mytologisk drømmetilstand, som vi stræber efter, men ikke kan nå. Det er en stærk drøm, der motiverer mange af vore handlinger. Vi skaber dem ved juletid. Vi prøver nabofællesskaber. Vi støtter det lokale fodboldhold. Vi prøver på mange måder og på mange niveauer at opnå trygheden og sikkerheden i det lokale fællesskab, i den lokale landsby.

Drømmen om fællesskabet bestemmer også, hvad vi læser i avisen, hvad vi ser på fjernsyn. Helt tilbage fra avisernes start har lokal identifikation været udnyttet til at skabe et publikum. Beretninger i avisen fra velkendte steder, om kendte personer ska- 
ber en følelse af tilhørsforhold. Den enkeltes oplevelser bekræftes og bestyrkes. Lokale aviser skaber en fælles oplevelse i et lokalområde ved at gøre det nære fælles. Uanset at folk i et lokalområde måske ikke kender hinanden, så kan avisen skabe en fornemmelse af samhørighed. Naboen, man måske aldrig har talt med, læser man om i avisen, når han får sit billede bragt, fordi han fylder år. Trafikuheldet på hjørnet bliver beskrevet i en notits dagen efter.

Det nære har altid været det vigtigste. Man er knyttet til dem, der er tættest på: Familien, klanen, lokalsamfundet. Man er mest interesseret i det, der sker udenfor ens egne vinduer, fordi det kan man se og „forstå“.

Studier af fremvæksten af pressen har demonstreret, at dagspressen altid har været lokal. I 1914 i Danmark havde vi 241 aviser med fire forskellige aviser i mange bysamfund (Jensen, 1997: 41). Forskellige i politiske holdninger, men alle lokale.

Aviserne var en integreret del i opbygningen af samfundet og var vigtige led i at skabe tilslutning til det nationale. Det var i den lokale presse, at den nationale dagsorden blev introduceret. Det var også her nyheder fra den helt store verden blev bragt. Nyheder om krig i fjerne lande og nyheder om hvilke skibe, der kom til havnen. Her fortaltes historier om „lokale“, der bliver berømte. Historier om lokale, der var i fare andre steder i verden. Om lokale firmaer, der opfandt noget vigtigt.

Avisernes informationer var og er knyttet til fundamentale menneskelige behov og den redaktionelle udvælgelse baseret på det simple forhold, at vi lever vores liv lokalt. Vi er placeret fysisk et sted, som vi kender bedre end andre steder; med mennesker, vi kender lidt bedre end andre mennesker. Her bor folk, vi har hørt om, med traditioner og ideer, vi er bekendte med. Vi har en verden, der er kendt, og som vi kan identificere os med, og en omverden der er ukendt, og hvor identifikation er vanskeligere. Som sociologer har påpeget er det ikke et „rigtigt“ fællesskab, hvor man kender hinanden. Det er et fællesskab, vi forestiller os. I opbygningen af et nationalt fællesskab spiller medierne en hovedrolle. Det er gennem dem, at tilhørsforholdet styrkes og formes. Det gælder nationalt, og det gælder lokalt (Andersson, 1983).

Bauman taler om „glokalisering“. Globaliseringen konstruerer 
det lokale, ved at revitalisere tradition (Bauman, 2001). Det lokale vælges som grundlag for modstanden mod hastige forandringer og modstand mod økonomiske, sociale og kulturelle grænsenedbrydninger. Andre forskere taler om, at lokalitet produceres. I det meget abstrakte begreb gemmer sig en beskrivelse af, hvordan man skaber sig en ny identitet gennem lokal tilknytning (Appadurai, 1991).

Samtidig med globaliseringen ser vi en vækst i tilknytningen til sprog, traditioner og ritualer. Det lokale er blevet vigtigere. Den region vi bor i er mere interessant. Tallene viser det. Over de sidste 12 år føler flere og flere danskere sig mere knyttet til den by eller det lokalområde, hvor de bor (Gundelach, 2002).

Udviklingen forstærkes af et oplevet skift i læserinteresse væk fra det politiske og over på en bredere nyhedsdagsorden. Mediernes udvikling fra nyhedsmedier til underholdningsmedier har givet den politisk dagsorden lavere status. Daværende chefredaktør Karsten Madsen, Berlingske Tidende, fortæller, hvordan redaktionen på avisen er svunget væk fra hard-core journalistikken og over mod et bredere nyhedsbegreb, nemlig ,den vinkel der har appel til hele familien, og som typisk vil have sit udspring $i$ boligforhold, sundhedsspørgsmål eller sociale problemer“. Nærvær skal nu være et af avisens kendetegn, siger han. (Esmann, 2002: 64).

Det brede nyhedsbegreb betyder, at det væsentligste er at få at vide, hvad der sker på den lokale skole og først derefter, hvad der ellers sker. Politik bliver vigtig, hvis den lokale skole eller sygehus er truet. Den politiske dagsorden bliver defineret nedefra- ikke oppefra.

Den lokale landsbytese har i det postmoderne samfund fået vind i sejlene. En stigende journalistisk orientering mod det lokale ses som løsningen på avisernes faldende betydning som medium. Færre annoncer, færre læsere og færre aviser er problemet. Mere lokalt stof er løsningen.

De elektroniske medier er blevet mere markeds- og modtagerorienterede. Resultatet har været en kraftig vækst i mængden af lokale nyheder, der tilbydes folk gennem særlige nyhedsprogrammer i radio og på tv-kanalerne. De nationale nyhedsmedier har ikke længere monopol på folks opmærksomhed. Lokale og 
regionale stationer har skabt et øget udbud af lokale nyheder. Medieforliget fra 2006 forstærker denne tendens ved at give mere sendetid til de regionale stationer.

Mens en stor del af de danske lokalaviser har lidt døden som selvstændige bladhuse, leverer gratisaviser, ugeaviser og landsog regionalaviserne mere lokalt stof til forbrugeren i dag end tidligere. Gennem special-sektioner, tillæg, gratisaviser og en general forøgelse af stofmængden er der i dag ikke nogen mangel på lokalt stof. Det er dét, læserne vil have, er argumentet (Poulsen, 1996).

Tilhængere af lokallandsbytesen kritiserer globalisternes antagelse om stigende interesse for det internationale. Den lokale læser er kun lejlighedsvis interesseret i det internationale. Det internationale er kun vigtigt, hvis der er en trussel. I brændpunktssituationerne interesserer alle sig for, hvad der sker globalt. Men interessen er baseret på en vurdering af, om det kan have konsekvenser for den „lokale“ sikkerhed, økonomi, miljø eller lignende. Det internationale er vigtigt, hvis det kan have konkrete lokale konsekvenser eller en konkret lokal brugsværdi. Det er derfor karakteren af den internationale situation der bestemmer, hvor meget intresse der er for det internationale.

Den lokale finder sin identitet i trygheden ved det kendte. Tradition er et bolværk mod for hastig forandring. Ønsket om at forhindre udefra kommende forandring viser sig bl.a. i, at i Danmark holdes EU modstanden i live. Eller det viser sig i det større fokus, der bliver sat på indvandring og de problemer, den medfører.

Mediernes og avisernes udfordring, sådan som den lokale ser dem, er at give de mange nyheder om trusler, forandringer og nye krav en tryg lokal eller national ramme. Mediernes dækning skal sætte verden på plads og gøre det utrygge trygt, gøre truslerne overkommelige, gøre den globale udfordring til en lokal overskuelighed.

Den journalistiske form og vinkel er vigtig for den lokale. Den journalistiske vinkel kan betone forskellighed eller lighed i behandlingen af det internationale. Historien kan vinkles, så den implicit styrker følelsen af fællesskab mellem danske læsere. Trusler kan beskrives, som kommende udefra. Vinklen kan beskrive det udefra kommende som en udfordring af det kendte. 
For den lokale læser vil det blive opfattet som en trussel. Historien om islam kan beskrives som en trussel, fordi den udfordrer snarere end tolererer etablerede traditioner.

Historien om udviklingen mod et Danmark sammensat af flere kulturer (multikulturalisme) kan ses som en trussel, fordi det sætter traditionens hegemoni på prøve. Informations chefredaktør David Trads spørger, om den massive dækning af islam og den muslimske kultur "har givet et retvisende billede, eller er den med til at skabe frygt $i$ stedet for forståelse" (Esman, 2002: 170).

Forøget kontakt skaber ikke altid forøget forståelse. Danmarks deltagelse i EU-samarbejdet er et eksempel. Historien om centralisering af magten i EU kan blive læst af den lokale læser som en trussel mod demokratisk selvbestemmelse. Jo mere centralisering jo mere er det en trussel mod det nære, mod miljøet, mod lokal selvbestemmelse.

Den lokale ønsker artikler, der sætter det internationale på plads. Enten ved at beskrive konflikter ude i verden som fjerne og derfor ikke farlige for os. Eller ved at eksplicitere, hvilken trussel denne konflikt sætter os i, hvad vi kan gøre ved det og hvem der har ansvaret for, at det bliver gjort.

Den danske vinkel er vigtig for den lokale læser. Det er den, der giver ham forståelse og identifikation af det internationale stof.

Den lokale accepterer i stort mål mediernes prioriteringer af stoffet, selvom han naturligvis kan være kritisk overfor enkelt dele. Det er vigtigt for ham, hvem der afsender nyhederne. Han har stor tillid til TV Avisen og sin daglige avis. Han vil gerne have meget lokalt stof og meget gerne have lokale vinkler på stoffet. Han læser navnestoffet, og han er interesseret i de små nyheder lige så meget som i de store. Han læser det internationale, hvis der er en krise, og hvis der er noget der presser sig på. Hvis der er en dramatisk udvikling og noget der er truende, så følger han det nøje, men han søger ikke selv informationer om det globale.

\section{Globale og lokale offentligheder}

Dagligdagen er både lokal og global. Både globaliseringen og dens modstand fylder mere i den enkeltes hverdag end nogen sinde før. Det lokale liv henne om hjørnet er ikke længere et af- 
sondret fristed eller en helle for den store verden. På samme tid er globaliseringen hverken en homogen eller altdominerende kraft.

Vi er naturligvis både lokale og globale. Som Baumann beskriver, skifter vi vores identitet på en problemfri måde, som vi skifter tøj. Vi kan være globale på arbejde, men lokale i vores fritid. Tidligere analyser har vist, at vi er ,internationalt interesserede, men lokalt forankrede" (Haahr og Holm, 2003). Vi har en global orientering, men er samtidig optaget af, hvad der sker omkring os. Kun et mindretal af den danske befolkning er enten globale eller lokale. Disse grupper findes, men det er mindre grupper i samfundet.

Kombinationen af det lokale og det globale er problemfri, indtil modsatrettede værdier eller handlinger støder sammen. Skal arbejdspladser sikres i Danmark eller er opgaven at sikre gode arbejdsbetingelser for alle: polakker, kinesere og danskere? Hvis vore værdier om retten til at drive hån og spot kommer i konflikt med andre menneskers religiøse opfattelse, hvad skal da være rettesnoren? Er ting som er forbudte i Danmark, f.eks. børnearbejde, også noget der skal være forbudt i alle de lande, vi handler med? Hvis kvindelig omskæring er forbudt i Danmark, kan vi så give bistand til lande, hvor det forekommer?

Kombinationen og sammenstødet mellem det lokale perspektiv og det globale perspektiv sætter en ny journalistisk udfordring på dagsordenen. Skal danske aviser redigeres udfra et hensyn, om hvad folk måtte mene, som ikke bor i Danmark, som ikke er en del af den vestlige offentlighed? Hvordan skal journalistikken stå i samfundets tjeneste, hvis det lokale, nationale og globale blandes?

Svaret er kompliceret: På den ene side er ønsket om global hensyntagen i praksis et næsten umuligt ønske. Vi har kun glimtvis en global offentlighed, og relevans og identifikation hos det primære publikum er en forudsætning for, at medierne kan tale til os. På en anden side er det åbenbart, at vi ikke kan ignorere, at den globale kontekst er blevet mere og mere fremtrædende. Danmark deltager i krige i fjerne lande. Vores erhvervsliv er globaliseret som aldrig før. Grupper i det danske samfund har en anden religion og andre normer end flertallet. Den journalistiske 
dagsorden må og skal afspejle, at grænserne bliver nedbrudt i befolkningens dagligdag.

Udfordringen er, at selvom vi er lokale, har vi et globalt ansvar. Den journalistiske opgave med at stille sig i offentlighedens tjeneste er ikke længere som læsernes eller lyttere og seeres talerør i forhold til danske myndigheder og det danske samfund. Det er også at forholde sig kritisk til den globale dagsorden.

På miljøområdet ser vi klare eksempler på, at dette journalistiske ansvar bliver løftet. Forurening i Kina, eller global opvarmning er vigtige emner på en relevant journalistisk dansk dagsorden. På andre områder er det ikke så indlysende. Diskussionen om Jyllands-Postens tegninger viste, at der ikke er fælles normer for, hvordan det journalistiske ansvar skal løftes, når vi taler om religiøse normer og hensyn. Skal vi udfordre andre religiøse normer, eller skal vi respektere dem? Hvor langt skal respekten gå i forhold til behovet for at rejse vigtige emner i den danske og globale offentlighed. Men også på andre områder forholder danske medier sig fortsat meget nationalt til den journalistisk dagsorden. Hvor mange gange bliver politikere i andre lande interviewet om deres syn på dansk lovgivning, der kan påvirke dem i andre lande? Skatteregler for selskabsbeskatning, uddannelsespolitik o.s.v? I dag stopper den journalistiske nysgerrighed typisk med udtalelser fra diverse danske politikere og den ansvarlige danske minister. Hermed synes sagen journalistisk set afsluttet.

I virkeligheden erkender de fleste, at meget få sager i dag afgøres af danske politikere alene. Og at meget få sager ikke har konsekvenser for andre lande og andre landes befolkninger. Den store og vanskelige journalistiske udfordring er, at løfte det journalistiske perspektiv væk fra det lokale og det nationale og over til en sagspecifik vinkling, der svarer til, hvad der er dagsordenens indhold. Den dominerende nationale vinkling fører til, at befolkningen lulles ind i en forestilling om, at der også er nationale løsninger eller, at vores værdier er de rigtige.

Andre af analyserne i dette nummer af Journalistica viser, at hvad enten der er tale om dækningen af den amerikanske valgkamp eller der er tale om EU-dækningen i Danmark, er den journalistiske målestok for væsentlighed båret af en forestilling om den nationale offentlighed, som det centrale forum for den jour- 
nalistiske dagsorden. EU-dækningen er blevet europæiseret, men vinklen er stadigt national (Ørsten, 2006; Lassen og Ishøy, 2006).

Pia Kjærsgaard sætter fingeren på det ømme punkt, når hun udtrykker ønsket om, at vi kan have Danmark i fred uden at isolere os. Men er det muligt? Er det ønskeligt? Hvem ønsker det? Hvad betyder det for vores økonomiske, sociale og politiske udvikling at vælge en sådan strategi.

Den journalistiske udfordring i en dagligdag sammensat af lokale, nationale og globale perspektiver er kritisk at forholde sig til alle tre dele af denne dagligdag. Det nytter ikke, at gøre det globale til naturkræfter, der kommer til os udefra, og som vi ikke kan ændre på. Der kan findes mange eksempler på denne type dækning i erhvervsjournalistikken. Globaliseringen bliver gjort til en vækstmodel, der ikke sættes under journalistisk kritik og afprøvning.

Offentligheden er blevet mere sammensat. Normer og hensyn fra andre kulturer skal journalistisk underkastes en kritisk vurdering. Politiske problemer i andre lande skal ikke afvises eller henvises til det interessante men mindre vigtige.

Journalistikken lever i et nationalt fængsel, hvor vi kigger ud mellem tremmerne, og får impulser ind gennem lugen, men hvor vi stadig mangler at konfrontere det globale i det lokale og det lokale i det globale. Stephen Ward har fremhævet at „vi er ved afslutningen af den traditionelle mainstream journalistiks dominans“. En kosmopolitansk journalistisk er kravet, mener han, og opstiller tre krav: Journalistik skal være en af de globale aktører i en global offentlighedssfære; tjene verdensborgerne; fremme ikke-fordomsbaseret forståelse.

Forøget kulturel forståelse i en pluralistisk verden er en dagsorden, der står i skærende kontrast til kravet om, at vi vil have Danmark i fred. Den journalistiske opgave er ikke blevet nemmere. 


\section{REFEREN CER}

Allan og Zelizer (2004) Stuart Allan og Barbera Zelizer, "Rules of Engagement" i Stuart Alllan og Barbera Zelizer (eds.), Reporting War, Journalism in Wartime, London: Routledge.

Anderson, Benedict (1983). Imagined Communities Reflections on the Origin and Spread of Nationalism, London and New York: Verso.

Appadurai, Arjun (1991). "Disjuncture and Difference in the Global Cultural Economy”, Theory, Culture and Society, vol. 7, pp. 295-310.

Bauman, Zygmunt (2001). Community. Seeking Safety in an Insecure World, Cambridge: Cambridge University Press.

Castells, Manuel (1997). The Power of Identity, London: Blackwell.

Esmann, Frank (red.) (2002). Nyhedskriterier i det 21. århundrede, København: DRs Forlag.

Giddens, Anthony (2000). En løbsk verden, København: Hans Reitzels Forlag.

Ginneken, Jap van (1998). Understanding Global News, London: Sage.

Gundelach, Peter (2002). Danskernes voerdier 1981-1999, København: Hans Reitzels.

Haahr, Jens Henrik og Hans-Henrik Holm (2003). Meget større end du tror. Avislaeserne og det internationale, Århus: Ajour.

Hall, Rodney Bruce (1999). National Collective Identity. Social Constructs and International Systems, New York: Columbia University Press.

Held, David et al. (1999). Global Transformations. Politics, Economics and Culture, Cambridge: Polity Press.

Hirst, G. P. Thompson (1996). Globalization in Question, Cambridge: Polity Press.

Holm, Hans-Henrik (1994). „Afrika i vore hjerter“, i Gorm Rye Olsen (red.), Afrika-det ukuelige kontinent, København: DRs forlag.

Holm, Hans-Henrik (2001). "The Effect of Globalization on Media Structures and Norms. Globalization and the Choice of Foreign News" i Stig Hjarvard (red.), News in a Globalised Society, Gøteborg: Nordicom.

Holm, Hans-Henrik, Lars Kabel, Torben Kitaj, Lars Møller og Flemming Ytzen (2000). Verden på tilbud. Om udenrigsjournalistik og mediernes udlandsdcekning, Århus: Ajour.

Jensen, Klaus Bruhn (red.) (1997). Dansk Medie Historie, København: Samleren. 
JP/Rambøl (2006). Opinionsundersøgelse offentliggjort Jyllands-Posten den 14. maj 2006.

Lassen, Laurits Harmer \& Søren Kjellberg Ishøy (2006). „Når politik bliver underholdning“, Journalistica, nr. 2, pp. 27-41.

McLuhan, Marshall (1964). Understanding media. The Extensions of Man, London: Blackwell.

Mulhull, Stephen and Adam Swift (1992). Liberals and Communitarians, London: Verso Press.

Poulsen, Jørgen (1996). Hvad ønsker laeserne?, Roskilde: RUC.

Taylor, Charles (1989). Sources of the Self: The making of modern identity, Cambridge: Polity Press.

Trads, David (2002). „Farlige Fjendebilleder“, pp. 170-184 i Frank Esmann (red.) (2002). Nyhedskriterier $i$ det 21. århundrede, København: DRs Forlag.

Volkmer, Ingrid (1999). News in the Global Sphere. A Study of CNN and its impact on Global Communication, Luton: Luton University Press.

Vreese, Claes de (2000). "Frames in Television News", i Stig Hjarvard (red.), News in a Globalised Society, Gøteborg: Nordicom.

Ward, Stephen (2006). “Global Journalists”, Toronto Star, May 6 ${ }^{\text {th }}, 2006$.

Waters, Malcolm (1995). Globalization, London: Routledge.

Ørsten, Mark (2006). „Europæisk offentlighed i danske medier - Danmark som foregangsland for udviklingen af en transnational politisk journalistik?“, Journalistica, nr. 2, pp. 103-119. 